\title{
The Terrible and Destructive Human Tragedy of Subaltern Kashmir in the light of Agha Shahid Ali's poetry
}

\author{
Dr. Mohd Yousuf Khan ${ }^{1}$, Peer Salim Jahangeer ${ }^{2}$
}

\author{
${ }^{1}$ B.Ed. M.Phil (English), Ph.D., Awadhesh Pratap Singh University, Rewa, MP, India \\ ${ }^{2}$ M. Phil English, M.Ed, Ph.D (English), Research Scholar, Awadhesh Pratap Singh University, Rewa, MP, India
}

\begin{abstract}
Ali depicted in general the terrible and destructive human tragedy of subaltern but in particular he put forth the subaltern voice of Kashmir in the landscape of his poetry, and this novelty emerges from the chaos of Kashmir. He had been educated in English and he develops the interest in English language and literature. So English literature has influenced him and his behavior had changed accordingly that he became well aware about postcoloniality. He wants to get rid from these clenches all the countries of the world as well as his motherland Kashmir which he also represented in his poetry. He is extremely worried not only with his previously colonized home 'the Indian subcontinent, particularly the region of Kashmir' but also with other cultures subject to the repercussion of colonialism and the modern neocolonial order. He writes poetry of 'compassionate cosmopolitanism,' which, fixed in his multi-cultural tradition, not only foregrounds an ethics of empathy across countrywide and civilizing limitations but also implies an assessment of colonial and neo-colonial power. His cosmopolitanism is especially meaningful if read in the context of postwar American travel poetry and enables review of the association between "home" and "foreign," between local issues and universal apprehensions.
\end{abstract}

Keywords - human tragedy, subaltern, Kashmir, apprehensions.

Ali's poetry is like a vessel for the history, poetry, politics- an extraordinary combination since "political poems" often become propagandist or factional. His poetry, superb in its use of language: the dramatic metaphors, the marvelous combinations and the merge of the genuine with the strange, remain poems and don't weaken into sloganeering. He had all the times enthusiastically revolted against the narrow-mindedness shown by the so called preachers who use the religion for their benefit. He was one of the writers who, signing the letter to the New York Times editor in 1989 to protest the fatwa against Rushdie, clarified that the movement against Rushdie was in fact "antithetical to the Islamic traditions of learning and tolerance." He has developed broad vision in his life because he was firstly nourished in such family, and also he spends most of his life in West. So he had become accustomed with social and secular life. As literature is reflection of life and he also reflected his life through his poetry. Thus his poems evidenced his emotion of loss, his associations, recollections, memories, visions also represented his individuality. With the help of his poetic creation he produced a national awareness on the international measurement. If his poetry can communicate the sentiment of exile and loss of home, his imagination can surpass uprootedness and can help him to take pleasure in his multinational approach. Keya Majumdar pertinently says:

Inventing, investigating and refashioning the self with all its fractured bits is the problem of all diasporic writings, especially poetry.

Kashmir, for the majority of Western readers, may only be a remote and mystical place, seldom encountered in literary or cultural scenes. His poems witness and also expose American readers to the suffering in the remote landscapes they might usually ignore either by lack of information or incorrect information. In the preface to his translation of Faiz Ahmed Faiz's poems, The Rebel's Silhouette, Ali notes, "In Faiz's poetry, suffering is seldom, perhaps never, private [...]. Though deeply personal, it is almost never isolated from a sense of history and injustice"(n.pag.). The same thing can be said about his own work. As a Kashmiri native, his witnessing departs from miserable, nostalgic personal feelings and develops into a sympathetic international view of the world. Kashmir in this witnessing becomes a point connected to other locations in 
the world map both historically and in the present. The rather "personal" homesickness, nostalgia, and lament for the death of Kashmiri natives are made intensely political, as the depicted Kashmir without doubt leads to an assessment of power. On one of the unusual occasions it does appear, in the beginning of Salman Rushdie's wellknown novel "Midnight"s Children", Kashmir, before partition, was described by what is called once paradise on the earth. So he presents Kashmir as paradise in several of his poems, which was the reality of that time. But time has changed the blooming paradise into the flaming hell by different agencies and Ali is the brave who represent the contemporary bleeding Kashmir in his poetry. He captures moments from these recent contrasts of the past with the help of some factual episodes of present situation and represents them in his poems. If Rushdie makes visible a harmonious Kashmir that belongs to the past, Ali‘s Kashmir poems reveal the current reality, marked by blood, despair, and darkness caused by complicated inter-national and inter-religious politics. The current situation of Kashmir can be exposed by the words of Ananya Jahanara Kabir as " Disappeared youth, raped women, intracommunal breakdown, interrupted childhoods, traumatized soldiers, and above all the thickness of rumour turned the region into a veritable "space of death" (9-10). As Patrick Colm Hogan has noted, Rushdie soon moves away from Kashmir and later suggests a tragic future for Kashmir in his book, yet the real situation is even more bleak and complicated than Rushdie suggests (539). Since partition, Kashmir has been transformed into a place of tensions and catastrophes:

This conflict between an indigenous tradition of practical identity that tends toward harmonization and an alien system of categorical identities that aligns religious affiliation with nationhood in sets of rigid antitheses-Muslim against Hindu, Pakistan against India- this conflict is no doubt one important cause of the pain and cruelty that have been so evident in Kashmir in recent years. (Hogan 539)

Agha Shahid Ali is a Kashmiri American poet; he can be referred as the poet who writes about the anxiety, anguish and tyranny imposed on the people of his motherland. There is a continuous sense of slaughter and expression of grief with political feeling of complaint omnipresent throughout his poetry. He mourns the trouncing of a paradise which is now sunken in the flood of blood of common masses gunned down by different agencies. According to a scholar of Guru Gobind Singh Indraprastha University Dwarka -New Delhi India Mansi Mehra M. Phil. in his article "Lamentation for the Lost
Culture: A Reading of Agha Shahid Ali's Poetry" "Lamentation of this lost Kashmir is scattered throughout the poetry of Agha Shahid Ali. He finds the culture, ethos, beauty of his beloved homeland being ripped, there are movements in his poetry which show his inability to comprehend the face of his homeland, which has now changed into a place "where shrines which were once revered by masses, are now being turned into ashes. Curfew and gunfire have replaced the melodious springs and saffron farms (Zaidi)". Thus he writes "At certain point I lost track of you". His verses take our attention towards "internal colonialism" and seek to explain the subordinate the status of a state within its own country." According to Javeria Khurshid, in an article Literary Responses to the Catastrophic 90s in the Un-Silent Valley: The Comparative Study of Agha Shahid Ali, Bashart Peer, and Mirza Waheed). "In 1990s there was demoralization and atrophy in the valley giving rise to total anarchy. A turmoil had started in the earthly paradise, with turbulent political as well as social activity taking place, devastating a common man's life pushing the youths to take up arms and turning the whole state upside down in the upheaval. Every now and then, Kashmir and its prolonged insurgency makes headlines and talk about the tragedy as if it were mere statistics but since 2008, the literary response to the catastrophic tragedy has gone through a process of renaissance. Although this literary reaction was well started by Agha Shahid Ali, the genius who made the literary world take note of Kashmir's ability to crate startling English Literature. Since 2008, both Baharat Peer and Mirza Waheed wrote about brutalized Kashmir, of turbulent times and the unfaltering hope in spite of the void that has been created. They gave the poignant tale of 1990s sufferings a literary expression and wove tales together that portray the reaction of people to this cataclysm." In fact, looked at this way, Kashmiri-English writing owes its genesis to Agh Shahid as his inheritance develops a sense of responsibility among some creative writers from Kashmir who are encouraged by him to write upon their motherland as faithful sons. It is, for that reason, that there was an increase in Kashmiri writing in English from the writing of Ali due to the influence of his poetry. So, it is Ali, who is a clear literary/psychological model for younger writers like Peer Bashrat and Mirza Waheed, who wrote "The Curfewed Nights" and "The Collaborator" respectly, providing for stong intertextual links between the trio. Rahul Pandita's "Our Moon has Blood Clots" has also the same voice. Basharat Peer's record about the valley titled "Curfewed Night" summons the image of a shadow searching for its 
body used by Agha Shahid Ali in his poem, "I See Kashmir from New Delhi at Midnight", also Mirza Waheed's “The Collaborator" begins with the same poem. Ali's poem "From Another Desert" in one can observe on superficial the love story of Qais (Majnoon) and Laila; but it has deeper meaning which Ali explains himself in its footnotes. $\mathrm{He}$ explains that this legend "has acquired a political dimension, in that Majnoon can represent the rebel, the revolutionary who is a model of commitment," and that "Laila thus becomes the revolutionary ideal, the goal the Lover/ Revolutionary aspires to reach". Ali is aware of the difficulty in regards to the territorial dispute over Kashmir among three nuclear countries: India, Pakistan, China, and the helpless people of Kashmir. Amitav Ghosh said that once Shahid had attended a dinner party at his home where he (Ghosh) asked him him (Ali): "What do you [Ali] think the solution of Kashmir?" His [Al's] answer was: "I [Ali] think ideally the best solution would be absolute autonomy within the Indian Union in the broadest sense," but given the current reality, he knew that "such a solution was [probably] no longer possible" (qtd. in Ghosh). Ananya Jahanara Kabir describes Kashmir, as follows:

"locked within inhospitable terrain, but professed by all to be a singularly beautiful place, the Valley has, in the course of the twentieth century, emerged as a bone of contention for three nationalisms, Indian , Pakistani and aspirant Kashmiri”. (Kabir,1)

Comparing the beauty of the place with that of heaven Agha Shahid Ali in the poem, "The Last Saffron" considers his motherland Kashmir as exceptionally admirable of being called a "paradise". The poet quotes the famous expressions of King Jahangir, when he makes praise about the magnificence of Kashmir; "If there is paradise on earth / it is this, it is this, it is this" (Ali 15). According to the scholar Rasheda Parveen in her article "AGHA SHAHID ALI'S ENGLISH GHAZALS AND THE TRANSNATIONAL POLITICS OF LITERARY SUBVERSION" which was published in journal "The Challenge" Vol. 23 No. 1 Jan - June 2014: "Torn between exact traditional representation of the genre and in a language academically inherited, Shahid Ali in no way seems to be able to side line the influence of cultural and lingual intermingling of his upbringing. Political turmoil and the subsequent self exile from the terrestrial heavenKashmir - present the epic distance of Man from Eden. Perfection and a state of bliss, transgressing man and generating a sense of imperfection, suffering and exile thoroughly predominate the poetic themes. The loss of Kashmir is the loss of homeland that is fragmented physically and textually as Shahid Ali reminiscences "PARADISE ON EARTH BECOMES HELL" (2009: 257; author's emphasis)". His poetry suggests a sense of dislocation that seems about original, and visualizes a reaching out to a home in the past, especially making center of attention on the figure of Kashmir as a remembered cultural space, as a physical place on which destroy and damage have been visited by different agencies and as a poetic 'Paradise' which once was, and even now is, paradise in spite of the fire and murder that has cleaned through it, in spite of the mass departures and the demonization. Agha Shahid Ali's poetry describes the story of the remembrance, desire and pain of a powerless spectator who sees from thousands of miles away his favorite Kashmir. Some critics like Lawrence Needham and Jeannie Chiu have discussed Ali‘s artistic vitality of exilic homesickness, miserable, and slaughter centered on Kashmir. According to a scholar Burhan Bashir in an article "Speaking Truth to Power: Resistance in Select Poems of Mahmoud Darwish and Agha Shahid Ali" which was published in European Academic Research Vol. IV. Issue 5/ August 2016 as: "The curfews in the 90s were order of the day, where people were ensnared in worst circumstances. Afraid of abstraction, poet speaker recalls the exact names of the places: "Zero Bridge," "Cantonment", and "Gupkar Road". Badami Bagh Cantonment is the largest military base situated in Srinagar and the Gupkar Road was notorious for its torture cells like Papa-2. The boys were taken here and tortured to extract the information. Among various other butcheries that were used to torture, the poet here mentions here the "drippings" of a "burning tire are falling on the back of a prisoner" and out of pain the boy screaming: "I know nothing"." Most of the poems of Ali are directly or indirectly concerned with his motherland Kashmir. These poems disclose the present actual situation by the son the land. They work like tongue for the dumb people of suffering Kashmir. He is extremely worried about his colonized motherland Kashmir which was subject to the repercussion of colonialism from the ancient times and now at present neocolonial order. Ali, lamenting the destruction of Srinagar, the summer capital of Jammu and Kashmir, thinks about the future of his mother land as a devoted son even though in exile. So his poetry will also be remembered for its nostalgic homage to Kashmir- the lost and damaged homeland. The idea of a ravished, brutal desecration runs throughout the state of Jammu and Kashmir. He merges shocking descriptions the Kashmir of blamelessness and magnificence now blood stained and brutal. This amalgamation of past and present, now and 
then often results in a hallucinatory simultaneity of experiencing- a poetic technique that may well be his signature style. The benumbing of a community is evoked in a matchless poetic technique and Amitav Ghosh pays the following tribute:

"If the twin terrors of insurgency and repression could be said to have engendered any single literary leitmotif, it is surely the narrative of the loss of Paradise. [...] [T] he reason why there is no greater sorrow than the recalling of times of joy, is [...] that this is a grief beyond consolation (Ghosh 308, 313)."

\section{REFERENCES}

[1] Agha, Shahid Ali. The Veiled Suite, The Collected Poems: Penguin Books India, 2009.

[2] ----------. Interview with Christine Benvenuto. The Massachusetts Review 43.2 (2002): 261-268.

[3] ---------. Interview with Deborah Klenotic, -Waiting for Word in the Paradise that was Kashmir.l March 17, 2007

[4] ----------. Interview with R. Ansari and Rajinder S. Paul. -Calligraphy of Coils.March 10, 2007

[5] Ghosh, Amitav. The Diaspora in Indian Culture from The Imam and the Indian: Prose Pieces, New Delhi: Ravi Dayal Publishers and Permanent Black, 2002.

[6] Javeria Khurshid. Literary Responses to the Catastrophic 90s in the Un-Silent Valley: The Comparative Study of Agha Shahid Ali, Basharat Peer, and Mirza Waheed, www.galaxyimrj.com.

[7] Nida Sajad. The Transnational Cartography of Agha Shahid Ali's poetry, Rocky Mountain Review. 